\title{
Pendampingan Komunitas Pengemis dalam Melestarikan Piwulang Kanjeng Sunan Drajat Lamongan
}

\author{
Miftachul Ulum, Abdul Mun'im, \& Sholihuddin \\ Institut Pesantren Sunan Drajat Lamongan \\ Email: drajatulum@gmail.com,munimdrajat@gmail.com
}

\begin{abstract}
Raden Qosim or better known as Kanjeng Sunan Drajat, is present in our midst and has colored the lives of Indonesians, especially the city of Lamongan. Concern and wisdom are still felt today with the concept of Piwulang Wenehono ... Wenehono ... ..... Wenehono ...... This concept gives the meaning of the command to always give... give ... give ... ... and not asking. But in reality not all citizens are aware of and understand the implicit meanings in it, some people only take advantage and take advantage of tourist areas as part of a way to make a living regardless of the sustainability of the site of Sunan Drajat. Economic inequality is the key to dying for someone to throw themselves into a puddle of life that is not in accordance with religious norms, some people decide to become beggars. The decision to become a beggar is based on economic factors, compulsion and cultural factors of his ancestors. Beggars coloring in the world of religious tourism, regardless of whether this is appropriate or as part of helping people to do charity
\end{abstract}

Abstrak: Raden Qosim, atau lebih dikenal sebagai Kanjeng Sunan Drajat, hadir di tengah-tengah kita dan telah mewarnai kehidupan orang Indonesia, khususnya kota Lamongan. Kepedulian dan kebijaksanaan masih terasa saat ini dengan konsep Piwulang Wenehono ... Wenehono .... ..... Wenehono ...... Konsep ini memberi arti perintah untuk selalu memberi..., memberi ... memberi ... ... dan bukan meminta. Tetapi pada kenyataannya tidak semua warga negara menyadari dan memahami makna implisit di dalamnya, sebagian orang hanya mengambil keuntungan dan memanfaat kawasan wisata sebagai bagian dari cara untuk mencari nafkah tanpa memperhatikan keberlangsungan situs Sunan Drajat. Kesenjangan ekonomi adalah kunci untuk mati bagi seseorang untuk melemparkan dirinya ke dalam kubangan kehidupan yang tidak sesuai dengan norma agama, sebagian orang memutuskan untuk menjadi pengemis. Keputusan menjadi pengemis didasari karena faktor ekonomi, keterpaksaan dan faktor budaya nenek moyangnya. Pengemis turut mewarnai di dunia wisata religi, tanpa memperdulikan apakah ini pantas atau sebagai bagian dari membantu orang untuk beramal.

Kata Kunci: Sunan Drajat. Piwulang, Pengemis, Wisata Religi. 


\section{PENDAHULUAN}

Menyebut Sunan Drajat sesuatu yang tidak asing bagi telinga kita, salah satu wali songo yang ikut andil dalam penyebaran Islam di nusantara. Kipra dan sepak terjang dalam pemikiran telah mewarnai kehidupan masyarakat Indonesia khususnya kota Lamongan. Kepedulian dan kearifannya pun masih terasa sampai saat ini walaupun sudah berlangsung kurang lebih 500 tahun yang lalu, hal ini ditandai dengan kehadiran para pejiarah setiap hari (Satori dan Agung 2017). Salah satu konsep pemikiran Kanjeng Sunan Drajat yang masa kecil di sebut Raden Qosim adalah wenehono, wenehono, wenehono ( berilah, berilah, berilah ) yang dapat kita lihat ketika kita masuk area pemakaman Sunan Drajat. Wenehono mangan marang wong luweh ( berilah makan bagi orang yang kelaparan ), Wenehono klambi marang wong udo ( berilah pakai bagi orang yang telanjang), Wenehono teken marang wong kang wuto ( berilah petunjuk bagi orang yang buta) dan Wenehono iyup iyupan marang wong kang kaudanan ( berilah payung bagi orang yang kehujanan ) . Syair-syair diatas merupakan salah satu konsep kehidupan yang diajarkan oleh kanjeng Sunan Drajat (Muzakki 2017).

Dewasa ini seiring adanya globalisasi yang di tandai dengan kemajuan dunia ilmu informasi dan teknologi, memberikan banyak perubahan dalan banyak hal bidang. Globalisasi adalah suatu keniscayaan yang tidak bisa dibendung bendung lagi. Di Indonesia globalisasi sudah bisa dirasakan oleh banyak orang dari generasi tua, muda sampai anak-anak, dengan segala dampak positif ataupun negatif (Miftachul Ulum 2018). Hal ini tidak diiringi dengan kepekaan masyarakat untuk mempertahankan jati diri dengan berbagai nilai budaya yang ada sehingga lambat laun konsep tersebut dapat mengalami pasang surut karena perubahan generasi (Gumilang 2017). Para pendatang atau pejiarah dengan berbagai macam kelompok juga turut merubah pola pikir masyarakat sekitar sebagai awal munculnya konsep tersebut. Tatanan kehidupan sosial masyarakat dan ditunjang kondisi ekonomi turut andil juga dalam perubahan pemahaman piwulang atau ajaran Kanjeng Sunan Drajat. Situs makam Sunan Drajat merupakan cagar budaya yang harus dilindungi, negara Indonesia berkembang dan tumbuh menjadi negara yang sejahtera tidak akan lepas dari tulisan sejarah yang telah di tulis oleh para wali songo, termasuk Kanjeng Sunan Drajat. Hampir tiap hari jumlah penjiarah mencapai kurang lebih 20.000 orang , dan dalam bulan-bulan tertentu dapat mencapai 100.000 perhari. Perkembangan jumlah pejiarah yang terus meningkat jelas akan berdampak pada perubahan perekonomian dan kondisi sosial disekitarnya.

Kehadiran para pejiarah memotivasi masyarakat sekitar , bahkan masyarakat luar kabupaten Lamongan untuk mengais rezeki dari wisata religi 
makam Sunan Drajat. Terdapat 700 pedagang yang mengisi kios-kios area parkir situs Makam Sunan Drajat, belum termasuk pedagang musiman atau yang mereka mampir untuk berjualan disekitar area makam. Mereka adalah para pedagang asongan yang turut meramaikan suasana lingkungan area situs makam Sunan Drajat. Disamping kehadiran para pedagang musiman juga muncul komunitas pedagang disekitar area situs makam Sunan Drajat. Mereka berada disekitar area tanah perdekan Sunan Drajat, mereka berada di sekeliling dan berada diluar tanah milik dinas pariwisata kabupaten Lamongan. Keberadaan mereka cukup ramai namun mereka jauh dari pengawasan dan pengelolaan dinas pariwisata.

Para komunitas pedagang yang lebih dikenal dengan "komunitas warung pangkon" hadir untuk mengais kehidupan ekonomi tanpa memperdulikan konsep pinulang atau ajaran dari para leluhur mereka, bahkan mereka pun belum tentu kenal atau tidak mengerti pinvulang atau ajaran tesebut. Para pemilik dan pengelola warung pangkon (istilah warung pangkon para penikmat kopi atau orang laki-laki yang duduk di paba gadis atau perempuan penyugub kopi) hanya tahu bagaimana mereka mendapatkan uang, tidak perduli apa konsep dan apa yang harus diperbuat untuk melestarikan cagar budaya ini. Kemajemukan dan perkembangan jaman turut andil dalam menggerus perubahan ini, perilaku sosial masyarakat turut andil dalam mempengaruhi perubahan pola pikir tanpa memperdulikan bagaimana cagar budaya ini lestari tanpa meninggalakan konsep aslinya. Mereka komunitas warung pangkon hadir dengan membawa atribut yang selalu menghiasi kondisi dirinya, mereka datang dengan karakter yang masing-masing, tanpa memperdulikan apa yang harus dilakukan untuk menanamkan cita-cita para leluhur mereka, mereka datang hanya satu tujuan dapat uang.

Selain para pedagang dengan warna atribut yang berbeda-beda baik dari pedagang asongan, pedagang musiman maupun pedagang menetap juga turut menjamurnya para pengemis. Para pengemis hadir di wilayah area makam Sunan Drajat, mereka turut juga mengais keuntungan dari para pejiarah. Aktifitas mereka yang mereka lakukan merupakan aktifitas keseharian dalam mencari mata pencaharian sehari-hari. Kehadiran para pengemis semakin hari, semakin bertambah sejalan dengan perkembangan wisata religi. Luas area parkir yang bertambah menunjukkan bahwa potensi kehadiran para pejiarah juga meningkat. Akses informasi akan keberadaan wisata religi juga semakin meluas yang berimbas bagi masyarakat yang akan datang juga meningkat termasuk para pengemis. Pengemis hadir dengan karakter dan latar belakang yang berbeda, faktor perekonomian, faktor tekanan sosial, faktor keluarga, faktor usia dan 
faktor lingkungan menjadi bagian dari pendorong untuk menjadi pengemis. Memutuskan menjadi pengemis adalah keputusan yang tepat bagi mereka yang dengan terpaksa maupun tidak yang secara sosial mengalami perubahan dalam proses berfikir.

Hasil studi pendahuluan dilapangan menunjukakan bahwa kegiatan pariwisata juga bisa dikatakan sebagai indikator terjadinya kontak sosial atau interaksi sosial masyarakat lokal dan wisatawan. Sebagaian memberikan dampak yang menguntungkan sebagaian juga memberikan dampak yang merugikan (Topowijono 2017). Hal ini terjadi bagi orang Indonesia terutama muslim Jawa sangat menyukai wisata relegi dengan mengunjungi makam para wali atau pemuka agama, mereka beranggapan barokah akan datang setelah berjiarah ke makam para wali atau pemuka agama. Mereka tidak bosan untuk berkunjung, berjiarah walaupun mengeluarkan biaya yang cukup besar. Terdapat suatu hubungan signifikan antara berjiarah kemakam para wali dengan ketenangan jiwa, begitu juga jika mereka berjiarah kemakam Sunan Drajat. Mereka beranggapan dalam sebuah mitos yang mengatakan mereka akan terangkat derajatnya jika telah berjiarah dan berdoa di makam Sunan Drajat.

Mitos yang telah mengakar di dalam jiwa masyarakat merupakan bagian terpenting dalam menjalankan kehidupan sosial namun kenyataan menjadi berubah jika kondisi lingkungan yang diharapkan telah mengalami penurunan karakteristik aslinya. Berawal dari kehadiran komunitas pengemis yang berada area dinas pariwisata situs Makam Sunan Drajat, yang berada di sekeliling cagar budaya Mereka datang sebagian besar dari masyarakat sekitar dan juga masyarakat pendatang yang hanya ingin mengais riziki dan keuntungan tanpa memperdulikan kondisi lingkungan cagar budaya, karakteristik dan perilaku yang berkembang di dalam masyarakat sekitar. Kondisi ini yang menjadikan suatu kemajemukan dan mengakar akan nilai cagar budaya Sunan Drajat dapat tergerus.

Setelah melakukan survei pendahuluan, peneliti mendapatkan realita di lapangan yang menunjukan bahwa di area situs makam Sunan Drajat terdapat permasalahan berupa sebagai berikut:

a. Masyarakat dampingan kurang memahami dan bahkan tidak mengenal tentang Sunan Drajat.

b. Masyarakat dampingan tidak mengenal ajaran dan konsep kehidupan yang diajarkan oleh Sunan Drajat.

c. Masyarakat dampingan berada di area Situs Sunan Drajat bertujuan untuk berbisnis tanpa memahami kondisi sosial dari Situs Makam Sunan Drajat 
d. Masyarakat dampingan tidak tersetuh sama sekali atau tidak memperdulikan dampak yang terjadi terhadap perubahan kondisi sosial masyarakat atas apa yang telah dilakukannya.

e. Masyarakat dampingan tidak memahami bagaimana melestarikan piwulang kanjeng Sunan Drajat .

f. Masyarakat dampingan perlu pembinaan dan penyadaran akan pentingnya hidup yang sesuai dengan ketentuan syariah

Melihat fenomena diatas maka peneliti optimis akan mampu mengubah situasi dan kondisi sulit yang sedang dialami masyarakat dampingan menjadi lebih baik, pendampingan ini berusaha memberdayaan masyarakat dengan memberikan ilmu, pengalaman, pembinaan, motivasi dan ikut serta memiliki situs makam Sunan Drajat, sehingga pada akhirnya, masyarakat dampingan akan mampu berubah menjadi lebih baik. Maka harapan dari dampingan adalah:

a. Masyarakat dampingan memiliki pengetahuan, pemahaman dan berbudaya sebagai bekal untuk menjalani kehidupan yang lebih baik.

b. Menjadikan kehidupan ekonomi masyarakat dampingan lebih mandiri , sejahtera dan bermartabat.

c. Menjadikan lingkungan situs Makam sunan Drajat sebagai inspirasi bagi masyarakat Lamongan dalam kehidupan yang berbudaya dalam menjalankan kehidupan bermasyarakat.

d. Tetap terjaga dan lestarinya cagar budaya situs Makam Sunan Drajat di Indonesia

e. Keluarga masyarakat dampingan dapat menjalini kehidupan dengan baik dan layak, sesuai dengan norma dan etika yang berlaku di masyarakat.

\section{TINJAUAN PUSTAKA}

Salah satu problematika yang sering dijumpai di lingkungan sekitar disebabkan antara jumlah angkatan kerja dan jumlah lapangan kerja yang tidak seimbang. Ketidakseimbangan antara jumlah angkatan kerja dan lapangan kerja terjadi karena banyak faktor. Kesenjangan sosial, kondisi politik, nilai jual hasil produksi yang rendah serta kepercayaan dunia industri menyebabkan kurang tersedianya lapangan pekerjaan. Ketersedianya lapangan kerja yang tidak memadai dapat menyebabkan banyaknya pengangguran, gelandangan, pengemis, kejahatan, perampokan, pelacuran atau terganggunya tempat-tempat umum karena banyaknya anak muda yang berkumpul di fasilitas-fasilitas umum, traffic light bahkan masuk di pemukiman warga. Salah satu problematika yang tidak pernah pudar dan masih eksis adalah menjamurnya para pengemis dan 
gelandangan. Berdasarkan pusat data dan informasi Kementerian Sosial (Pusdatin Kemensos), dimana Provinsi Jawa Timur adalah pusat populasi terbesar gepeng ( gelandangan dan pengemis ). Hal ini dapat dilihat dari data tahun 2011, dari 3 (tiga) provinsi terbesar di Pulau Jawa, dimana urutan pertama Jawa Timur dengan jumlah gepeng sebesar 2,088 jiwa, Jawa Tengah 1,318 jiwa, dan Jawa Barat dan DKI Jakarta sebesar 1,071 jiwa (Riyanto 2018).

Data diatas menunjukkan bahwa Jawa Timur memberikan andil yang besar terhadap populasi para pengemis. Para gelandangan dan pengemis biasanya mangkal pada daerah-daerah hiburan, terminal, pusat-pusat perdagangan dan tak terkecuali pusat wisata religi. Wisata religi menjadikan nuasa yang sangat harmonis dan menguntungkan bagi para pengemis, hal ini didasari oleh keyakinan bahwa dengan berjiarah untuk mengalap barokah menjadi salah satu momentum untuk mengetuk belaskasih seseorang untuk beramal melalui uang recehan. Para pejiarah tidak akan pernah memperdulikan dengan sedikit uang recehan untuk mengamalkan dirinya dalam meningkatkan ibadahnya. Melalui momentum inilah para pengemis memberanikan diri dengan menutup perasaan hati untuk terjun dalam dunia profesi sebagai pengemis.

Berdasarkan PP No 31 tahun 1980 dikatakan bahwa gelandangan didefinisikan sebagai orang-orang yang hidup dalam keadaan tidak sesuai dengan norma kehidupan yang layak dalam masyarakat setempat, tidak mempunyai tempat tinggal dan pekerjaan yang tetap dan hidup mengembara di tempat umum, sedangkan pengemis adalah orang-orang yang mendapatkan penghasilan dengan meminta-minta di tempat umum dengan berbagai cara/alasan untuk mendapatkan belas kasihan dari orang lain. Gepeng (gelandangan dan pengemis) merupakan suatu fenomena sosial yang harus ditanggapi dengan serius (Tyas Martika Anggriana 2016). Menelisik dari Peraturan Pemerintah No 31 tahun 1980 adalah sangat kontras dengan apa yang disampaikan oleh Ridwan Kamil walikota Bandung yang menawari sejumlah pengemis dengan pekerjaan baru sebagai penyapu jalan. Para pengemis itu menolak mentah - mentah karena hanya dibayar Rp 700,000 sebulannya. Mereka meminta gaji Rp 4 juta hingga Rp 10 juta perbulan. Permintaan gaji pengemis Bandung ini kiranya merupakan gambaran langsung pendapatan mereka sebagai pengemis(Simbolon, Windia, dan Sudarma 2016).

Argumentasi diatas merupakan bagian tersendiri dari rasa egoisme dari seorang pengemis, bahwa dengan mengemis akan memberikan keuntungan finansial yang cukup besar jika dibandingkan sebagai tukang sapu, pengemis dapat meningkat level perekonomian yang lebih baik tanpa harus bekerja, tanpa harus keluar keringat yang banyak sekali, tanpa punya resiko dalam berbisnis. 
Namun dunia ini menjadi begitu naif jika kenyataan dalam kehidupan ini dipenuhi dengan para pengemis. Pengemis dengan mudah sekali mendapatkan uang, dengan bermalas-malasan, tanpa beban kerja , tanpa mengkonsep kerja, tanpa merasakan pahitnya bekerja, tanpa keluar keringat tapi mendapatkan uang yang banyak.

Menurut Umi Supraptiningsih, Dosen Jurusan Syari'ah STAIN Pamekasan bahwa potret pengemis membuat pandangan tidak nyaman bagi para pendatang atau tamu yang berkunjung ke Kab. Pamekasan, gambaran kemiskinan yang sering nampak bahkan di beberapa tempat wisata di Kab. Pamekasan (api take kunjung padam dan arek lancor), etika para pengemispun kurang sopan, ada kesan pengemis memaksa untuk diberi (dengan cara menarik-narik baju para pengunjung) (Umi Supraptiningsih 2016). Mengomentari pendapat Umi supraptiningsih memberikan gambaran bahwa menjadi pengemis bukan merupakan suatu profesi yang dilegalkan, tapi menjadi sebuah barometer kemiskinan di negeri ini, karena pengemis identik dengan kemiskinan.

Hasil penelitian yang dilakukan oleh M. Ali Alhumaidy (2003) menunjukkan bahwa pengemis profesional akan melakukan transformasi nilai di dalam keluarga secara intens. Sejak kecil anggota keluarga terlibat dalam mencari dan mengelola uang dengan cara mengemis, sehingga mengemis telah tertanam dalam diri setiap anggota keluarga, dan pekerjaan mengemis itu tidak saja halal tetapi juga mulia. Dengan cara mengemis, terbukti kebutuhan dan keperluan keluarga terpenuhi, sehingga mengemis merupakan jalan panjang bagi pengemis profesional untuk tetap survival (Maghfur Ahmad 2010). Menurut Susanto seseorang atau sekelompok masyarakat dapat menjadi miskin karena berbagai faktor penyebab yang bisa dilihat dari dimensi karena keterbatasan ak-ses, pendapatan maupun pengeluaran yang subsisten, kondisi yang rentan terhadap penyakit, sering terlibat di dalam utang piutang, maupun harus menjual barang yang dimiliki untuk kebutuhan subsisten dan keadaan yang darurat dan secara sosial mereka tersisih dari berbagai pusat kehidupan serta memiliki hubungan yang terbatas, khususnya dalam ke-hidupan sosial di mana mereka tinggal dan beraktivitas sehari - harinya (Astrini Merlindha 2015). Menurut Tyas Martika Anggriana dan Noviyanti Kartika Dewi, beberapa permasalahan yang dialami oleh gelandangan dan pengemis adalah terkait dengan masalah ekonomi, masalah pendidikan, masalah sosial budaya, masalah lingkungan serta masalah hukum dan kewarganegaraan. Masalah ekonomi yang dialami adalah tentang masalah kemiskinan. Para gelandangan dan pengemis berasal dari golongan ekonomi bawah yang berada pada garis kemiskinan (Tyas Martika Anggriana 2016). 
Konotasi sebagai pengemis juga disuarakan bagi mereka yang terlanjur jadi pengemis, mereka membuat suatu alibi bahwa mengemis merupakan suatu perbuatan yang mulia jika dibandingkan dengan perbuatan yang lain seperti mencuri atau melacurkan diri. Pernyataan ini disampaikan Dusri 40 tahun "Ngemis lebib mulai dari pada maling." Kalimat itulah yang sering muncul dari mulut teman-teman yang mancari penghasilan dari jalanan. Meminta-minta merupakan langkah patriotic bagi orang seperti Dusri (40 th). Cara mempertahankan hidup dengan jalan menelusuri setiap jengkal Alun-alun kota Pekalongan bukan keputusan instan yang diambil secara tiba-tiba. Dusri melabuhkan aktivitas ekonominya sebagai peminta-minta setelah usaha dan kerja keras yang dilakukan mengalami kegagalan dan jalan buntu. Baginya, dengan cara mengemis di jalanan, berarti kebutuhan hidupnya terpenuhi dengan cara yang halal. Dusri menuturkan: "kulo seneng, syukur isih iso kanggo nyukupi urip (masih bisa mencukupi kebutuhan hidupnya), ...ngak malu, dadi pengemis luweh apik tinimbang maling (menjadi seorang peminta-minta lebih baik dari pada menjadi seorang pencuri) (Maghfur Ahmad 2010)

\section{METODE DAMPINGAN}

Pendekatan dalam penelitian ini menggunakan pendekatan kualitatif (qualitative approach) karena data yang dikumpulkan lebih banyak menggunakan data kualitatif dimana pendampingan ini lebih mengarah pembentukan partisipasi pada dampingan (Faisol 2005). Metode deskriptif ini dimaksudkan untuk memperoleh gambaran yang benar dan jelas, sehingga dapat memberikan data seteliti mungkin tentang obyek yang diteliti. Dalam hal ini untuk menggambarkan kondisi masyarakat yang mempunyai kebiasaan mengemis.

Pada penelitian kualitatif juga ditandai dengan menggunakan metode pengumpulan data yang berupa participant observation ( pengamatan dengan melibatkan dampingan) dan indepth interview (interview secara mendalam ). Peneliti berusaha untuk memaknai dan menafsirkan fenomena yang ada berdasarkan apa yang dirasakan oleh para informan dan diharapkan dapat memperoleh pemahaman yang mendalam dan murni tentang fenomena yang diteliti. Berikut ini beberapa tahap dalam kegiatan pendampingan

\section{Riset Pendahuluan}

Kegiatan ini meliputi survey lapangan tepatnya di area wisata religi makam Sunan Drajat yaitu melihat kondisi dampingan. Peneliti akan melakukan observasi untuk mengetahui kegiatan masyarakat sehari-hari, melihat bagaimana perilaku dan kebiasaan masyarakat, sosial masyarakat, lingkungan masyarakat, mengamati permasalahan yang terjadi di lingkup masyarakat dan melakukan 
wawancara untuk memperoleh data (Miftachul Ulum 2013). Sumber data diperoleh dari masyarakat sekitar, pedagang, pengelola wisata dan pihak-pihak yang terkait dengan kondisi dampingan. Potensi kondisi awal ini akan membukakan jalan unuk menelusuri permasalahan yang terjadi serta bagaimana kaitannya dengan kebijakan yang telah berjalan selama ini.

\section{Inkulturasi}

Dalam kegiatan ini, peneliti yang langsung akan ikut membaur dilingkungan tempat dampingan. Peneliti akan ikut nongkrong diberbagai dilokasi tempat para pengemis menjalankan aksinya. Di area Wisata Relegi Makam Sunan Drajat terdapat beberapa tempat mangkalnya para pengemis yaitu pertama sebelah timur area makam tepanya pintu keluar para pejiarah, kedua timur masjid dalem Makam Sunan Drajat, masjid dengan ornamen dari kayu berbentuk panggung, ketiga depan area musium Sunan Drajat dan keempat area parkir sebelah barat menuju pintu masuk makam Sunan Drajat. Dalam kegiatan ini peneliti berusaha untuk mengajak, mengarahkan dan memahami kondisi sosial yang dihadapi. Membaur dalam aktifitas kegiatan disekitar mereka dalam memahami aktifitas, pola perilaku dan mengetahui berapa pendapatan yang mereka peroleh dalam setiap harinya. Pola kegiatan mereka dalam meminta dari para pejiarah, serta perasaan ketika mereka tidak diberi oleh para pejiarah.

\section{Pengorganisasian Masyarakat}

Dalam langkah ini kami mengadakan komunikasi dengan masyarakat desa Drajat, pihak tokoh masyarakat, pemerintah desa dan para pengelola wisata religi dalam membicarakan kondisi dan problematika yang sedang terjadi. Dalam tahapan ini selain mengadakan sosialisasi dalam mendukung program tersebut. Informasi dalam suatu diskusi dapat memberikan gambaran yang sebenarnya atas kebijakan yang terjadi selama ini. Melalui Focus Grup Discussion (FGD) yang kita bentuk dapat memetakan dan mencari jalan tengah atas kondisi dampingan.

\section{Perencanaan Tindakan Aksi dan Strategi}

Dari tim yang telah terbentuk, kami merencanakan penyusun program kegiatan , serta langkah-langkah yang akan dicapai. Dalam hal ini koordinasi antar anggota perlu digiatkan. Kegiatan ini dimulai dari tahap awal menelusuri kegiatan para pengemis di area makam sebagi tempat mangkal, beberapa tempat mangkal yang mereka gunakan akan memebrikan gambaran, termasuk mengapa mereka lebih memilih diarea tertentu tidak mau pindah ketempat area satu kearea yang lainnya. Kegiatan ini kita bagi dengan beberapa periode baik waktu pagi, siang atau malam. Dari beberapa anggota tim selalu bergiliran agar informasi yang terkumpul dapat dipakai untuk membuat langkah selanjutnya. 


\section{Melakukan Pemetaan Partisipatif}

Dari hasil penelusuran dari berbagai sumber, maka langkah berikutnya adalah memetakan ujung masalah yang terjadi bagi pendampingan. Dari pendekatan yang telah dilakukan oleh tim, maka kita berusaha agar partisipasi yang dimunculkan dapat dikurai dari para dampingan. Tim menyediakan ruang rublik konsulatasi yang sedang dihadapi para dampingan. Skala konsultasi yang diberikan tim sangat fleksibel, menyesuaikan kondisi dampingan. Anggota tim berusaha menyisiri mengapa para dampingan berada dalam lingkungan dan hidup dalam kondisi dengan membaur dalam kehidupan sehari hari. Kadang kadang perasaan para dampingan merasa terusik dengan kehadiran kita karena mereka menjadi tidak bebas, dan punya perasaan kurang nyaman. Kita tetap berusaha menjaga bagaimana mereka tidak merasa terganggu dengan aktifitas kita.

\section{HASIL PENELITIAN DAN PEMBAHASAN}

Mengutip dari sebagian dari penelitian Astrini Merlindha dan Getar Hati bahwa faktor penyebab gelandangan dan pengemis dalam panti disebabkan karena faktor internal yang meliputi kemiskinan, sikap mental dan harga diri yang rendah. Se-dangkan faktor-faktor eksternal juga sangat mempengaruhi seseorang dapat melakukan aktivitas gelandangan dan pengemis (Astrini Merlindha 2015). Sedangkan menurut Tyas Martika Anggriana dan Noviyanti Kartika Dewi bahwa permasalahan yang terjadi pada warga binaan selama mengikuti rehabilitasi sosial di UPT RSGP relatif beragam. Permasalahan terkait masalah pribadi, ekonomi, tersebut pelanggaran terhadap aturan yang berlaku di RSGP, pencurian, kekerasan dalam rumah tangga, dan kecemburuan terhadap pasangan (Topowijono 2017). Dari hasil penelitian pendampingan yang kami lakukan terhadap para pengemis yang berada di area wisata religi Makam Sunan Drajat maka dapat kami rangkum bahwa faktor kemiskinan yang mendorong seseorang untuk menjadi pengemis. Menjadi pengemis merupakan solusi cepat tanpa mempertimbangkan perasaan malu untuk memperoleh uang dalam memenuhi kebutuhan hidup sehari-hari. Namun dalam penelusuran tim tidak selamanya kehidupan pengemis selalu miskin dan harus dengan menjadi pengemis. Dari penelusuran tim sampai ke tempat tinggal pengemis memang nampak rumah pengemis bukan termasuk tipe rumah huni yang tidak layak huni, dan tidak punya sama sekali harta kekayaan. Sebagai contoh pengemis bernama Kasmi 63 tahun, hidup dengan suami dan 2 putri , suami tidak bekerja dengan alasan yang kurang jelas, secara kesehatan masih sehat, anak perempuan juga masih sehat untuk bekerja namun akhirnya juga ikut menjadi pengemis. Rumah 
yang sederhana namun dilengkapi dengan antene parabola nampak tidak menunjukkan miskin serta satu unit sepeda motor vario tahun 2010. Jika menelisik kondisi tersebut maka bukan faktor utama kemiskinan menjadi penyebab menjadi pengemis.

Faktor Cacat fisik seseorang memutuskan untuk menjadi pengemis. Pilihan menjadi pengemis menjadi pilihan yang utama, karena yang paling mudah dan tidak banyak persyaratan untuk memperoleh uang dengan cara mengemis. Ahmadi 54 tahun, cacat kaki memutuskan mengemis dan penghasilan melebihi dari pendapatan orang yang bekerja sebagai kuli bangunan. Setiap bagi mangkal di timur pintu makam dengan diatar dengan becak motor dan sore hari dijemput oleh orang yang sama.Cacat tubuh karena kecelakaan menjadi pemicu untuk memutuskan menjadi pengemis karena tanggungjawab keluarga.

Faktor Usia mendorong seseorang untuk mengemis, karena faktor usia akan memberikan rasa prihatin atau belas kasihan para pejiarah untuk memberikan uang kepada para pengemis yang sudah lanjut usia. Maryam 45 tahun, umur tidak terlalu tua namun setiah hari harus mengemis diarea makam Sunan Drajat, kebiasaan ini dilakukan karena tidak ada pilihan lain kecuali mengemis dan sangat mudah sekali untuk melakukannya, ternyata faktor usia bagi Maryam bukan menjadi sebab untuk mengemis, faktor himpitan ekonomi menjadi pemicu awalnya dan karena lebih mudah, lancar dalam pemenuhan kebutuhan melalui mengemis sehingga profesi mengemis menjadi pilihan hidup. Maryam menjadi tergantung untuk menjadikan pengemis sebagai profesi, mau meninggalkan berat karena secara hitungan pendapatan mengemis lebih menjanjikan daripada bisnis yang kadang -kadang harus merugi.

Faktor budaya atau kebiasaan dari leluhur nenek moyang yang dulunya juga pengemis, walaupun tidak semuanya keluarga pengemis kemudian mewarisi menjadi pengemis. Sebagai contoh Mak Pa umur 54 tahun, hidup dengan seorang suami dan seorang anak, 2 anak yang lainnya telah berumah tangga. Kehidupan setiap hari rumah tidak terlalu mewah tetapi rumah sudah sangat layak, lantai berkeramik dan bertembok. Suami sebagai tukang bangunan yang secara penghasilan sebenarnya sudah cukup untuk menghidupinya, fasilitas dengan 2 sepeda motor sebagai alat transportasi setiap hari. Mak Pa memutuskan tetap mengemis karena nenek moyang mereka juga ada yang mengemis, walaupun sudah dilarang oleh keluarga namun kebiasaan ini tetap dijalani karena sudah menjadi kebiasaan. Perasaan malu akan mengemis sudah hilang dalam dirinya, mereka berprinsip yang menting saya tidak mencuri dan tidak mengganggu orang lain. Lebih uniknya lagi terdapat profesi ganda yang di jalankan dari sebagian pengemis, selain menjadi pengemis juga melayani 
penukaran uang recehan, ketika dia melayani penukaran uang maka disisi tempat penukaran uang ada keluarga yang menjadi pengemis.

Para pengemis rata-rata enggan untuk meninggalkan kebiasaan menjadi pengemis, bahkan dalam pengamatan selama ini kebiasaan mengemis seakanakan menjadi solusi yang paling tepat, tanpa resiko untuk mendapatkan penghasilan dengan cara yang paling mudah sekali, bahkan pada waktu tertentu mereka mengajak anak-anaknya untuk mengemis ketika sekolah libur. Dalam pantau peneliti ketika habis waktu subuh sebagian pengemis sudah berada dilokasi sementara anaknya sudah bersiap-siap untuk berangkat sekolah. Para pengemis sebagian besar adalah ibu-ibu rumah tangga, anak-anak sifatnya kondisonal dan laki-laki dewasa beberapa orang yaang karena faktor cacat fisik sehingga memutuskan mengemis. Para perempuan pengemis secara ekonomi bertujuan membantu suami dalam menambah penghasilan, mereka bergerak karena faktor kemampuan secara ekonomi kurang, dengan mengemis maka perekonomian suami menjadi dapat terbantu. Dalam penelusuran terhadap para pengemis yang sebagian dari kamunitas pengemis bertempat tinggal hidup desa Drajat tetap dapat menyesuaikan dengan keadaan kegiatan kemasyarakatan, seperti tahtimul qur'an, jamiyah yasinan dan jamiyah pengajian rutinan. Mengemis tetap mereka jalankan pada waktu pagi sampai siang setelah urusan rumah tangga selesai namun pada kegiatan kemasyarakatan mereka tetap aktif melaksankannya.

Dalam penanganan para pengemis pihak pengelola kurang respon sekali dalam menanggulangi biar tidak ada pengemis disekitar area makam. Pengelola membiarkan karena alasan faktor tuntutan ekonomi dan yang terpenting mereka tidak mengganggu para pejiarah yang sedang berada di area makam, para pengelola juga beralasan bahwa sebagian pengemis adalah masyarakat desa sekitar yang ingin mendapatkan uang untuk kehidupan mereka, yang penting tidak mencuri atau sampai terjun didunia hitam. Sebagian dari para pengemis juga turut memberikan kontribusi bagi kebersihan area makam yang cukup luas dengan banyaknya pohon pohon disekitar area makam. Mereka membersihkan area lingkungan makam setiap pagi sebelum menjalankan aktifitas sebagai pengemis.

Kegiatan kebersihan yang mereka lakukan juga membantu pengelola untuk mewujudkan lingkungan area makam menjadi bersih. Para pengemis menyadari akan kekurangan dan pemahaman arti penting slogan atau piwulang yang telah terpampang di pintu masuk makam Sunan Drajat. Melalui pendampingan para pengemis berusaha menjaga, melestarikan dan mengaplikasikan dalam 
kehidupan sehari-hari. Bahwa dalam ajaran Kanjeng Sunan Drajat tercermin sifat untuk memberi...memberi....dan memberi bukan meminta.

Hal ini menjadi penyadar bahwa mengemis adalah bertolak belakang dari piwulang yang disampaikan kanjeng Sunan Drajat. Namun kenyataan tetap pada kondisi semula bahwa mengemis seakan-akan menjadi panggilan jiwa, sehingga mereka para pengemis tidak dapat meninggalkan profesi sebagai pengemis. Dari beberapa dampingan hanya sebagian kecil yang meninggalkan profesi sebagai pengemis dengan alasan kuatir nanti pengemis akan selalu menjadi profresi turun temurun bagi keturunannya, sadar bahwa mengemis adalah perbuatan yang kurang baik, dan menjadi sampah masyarakat. Memutuskan untuk tidak menjadi pengemis adalah keputusan yang paling tepat untuk memulai kehidupan yang lebih baik, tidak selalu bergantung dan menggantungkan uluran tangan orang lain. Menghargai tubuh dengan tetesan keringat, melalui bekerja yang halal.

Ketidakberdayaan bagi pengelola wisata untuk menolak agar para pengemis menjauh dan tidak berada diarea wisata religi Makam Sunan Drajat adalah suatu keniscayaan, dan tidak akan dapat menyentuh para pengemis untuk meninggalkan profesinya. Sebagian besar para pengelola wisata, tokoh masyarakat dan para pengemis adalah masyarakat sekitar wisata religi, ketidakberdayaan dengan menolak tidak mengemis atau menjadi pengemis adalah sesuatu yang bertolak belakang. Perangkat desa dan tokoh masyarakat menyadari bahwa para pengemis adalah warga masyarakat yang butuh untuk hidup, mereka sangat menggantungkan perekonomian dari mengemis.

Situs Makam Sunan Drajat selain sebagai simbol siar Islam juga menjadi magnet penggerak perekonomian masyarakat desa Drajat dan sekitarnya, perputaran perekonomian sebanding banyaknya pejiarah yang setiap hari hadir di tempat wisata. Masyarakat sangat menggantungkan kehidupan sehari-hari di Makam Sunan Drajat tak terkecuali kelompok komunitas pengemis yang hadir tanpa diharapkan, dibiarkan tak kuasa untuk menolak. Sama-sama hadir hanya untuk mengais perekonomian tanpa menimbulkan suatu perselisihan, tanpa pengerusakan , sama -sama harus melestarikan nilai budaya, nilai ajaran yang telah ditanamkan Kanjeng Sunan Drajat. Komunitas pengemis hadir dengan karakter yang berbeda, dengan kekuatan yang berbeda. Ketidak mampuan pengelola dan pemerintah untuk meminimalisasi atau menghilangkan para pengemis menunjukkan ketidakberdayaan dalam suatu kemiskinan. Masyarakat semakin beraneka ragam, kondisi sosial semakin berkembang searah dengan perkembangan teknologi. 


\section{KESIMPULAN}

Ada suatu kesenjangan dalam perekonomian yang menyebabkan sesorang menghinakan diri dalam kubangan kehidupan yang tidak sesuai dengan norma agama. Seseorang mengambil suatu keputusan tanpa berpikir panjang tentang akibat yang akan diterima dimasa yang akan datang. Dalam hal ini seorang mengambil suatu keputusan hanya menjadi pengemis, bukan hanya peminta tapi berprofesi.. Faktor kondisi sosial, kemiskinan, tekanan hidup dan lingkungan mendukung seseorang untuk berprofesi yang sudah mengesampingkan perasaan malu. Mengemis merupakan bagian profesi baru mereka yang membentuk komunitas para pengemis. Pengemis turut mewarnai potret buram dalam kehidupan bermasyarakat. Begitu mudahnya masyarakat saat ini memeilih mengemis bagian dari cara untuk melangsungkan kehidupan, mengais rezeki dengan meminta-minta. Melalui pendampingan ini paling tidak telah membukakan hati dan perasaan agar kehidupan dan orientasinya menjadi lebih baik. [

\section{DAFTAR PUSTAKA}

Astrini Merlindha, Getar Hati. 2015. "Upaya Rehabilitasi Sosial Dalam

Penanganan Gelandangan Dan Pengemis Di Provinsi Dki Jakarta." Jurnal Ilmu Kesehatan Sosial 16(1): 60-73.

Faisol, Abdullah. 2005. Metode dan Teknik Kuliah Kerja Nyata Transformatif: Implementasi Participatory Action Research (PAR) dan Participatory Rural Appraisal (PRA) Untuk. Aksi Perubahan Sosial. 1 ed. Surakarta: P3M STAIN Surakarta.

Gumilang, Galang Surya. 2017. "Internalization Of Philosophical Value 'Tembang Macapat' In Guidance And Counseling." In Prosiding SNBK (Seminar Nasional Bimbingan dan Konseling), Program Studi Bimbingan dan Konseling FKIP Universitas PGRI Madiun, 62-77.

Maghfur Ahmad. 2010. "Strategi Kelangsungan Hidup Gelandangan-Pengemis (Gepeng)." Jurnal Penelitian 7(9): 1-16.

Miftachul Ulum. 2013. Mahir analisis data SPSS : statistical product, service solution. I. Yogyakarta: Ghaneswara.

—. 2018. "Pembentukan Karakter Siswa Melalui Pendidikan Berbasis Pondok Pesantren.” EVALUASI 2(2): 382-97.

Muzakki, Ahmad Wafi. 2017. Prosiding Seminar Pendidikan Nasional 
Humanisme Religious Sunan Drajat sebagai Nilai Sejarah dan Kearifan Lokal.

Riyanto, Ditha Ardelina. 2018. "Kinerja Unit Pelaksana Teknis (Upt) Liponsos

Keputih Surabaya Dalam Pelayanan Sosial Dasar Bagi Gelandangan Dan Pengemis." Program Studi Imu Administrasi Negara Departemen Administrasi, Fakultas Ilmu Sosial dan Ilmu Politik, Universitas Airlangga 5(1): 1-11.

Satori, Akhmad, dan Subhan Agung. 2017. "International journal of multicultural and multireligious understanding." International Journal of Multicultural and Multireligious Understanding 4(1): 15-24. http://ijmmu.com/index.php/ijmmu/article/view/62/59.

Simbolon, Torkis Joel, I Wayan Windia, dan I Made Sudarma. 2016. "Perbandingan Pendapatan Petani dengan Pendapatan Pengemis di Kota Denpasar." E-Jurnal Agrobisnis dan Agrowisata 5(2): 460-67.

Topowijono, Muhammad Fahrizal Anwar Djamhur Hamid. 2017. "Analisis Dampak Pengembangan Wisata Religi Makam Sunan Maulana Malik Ibrahim dalam Kehidupan Sosial Dan Ekonomi Masyarakat Sekitar (Studi Pada Kelurahan Gapurosukolilo Kabupaten Gresik)." Jurnal Administrasi Bisnis ( JAB ) 44(1): 186-93.

Tyas Martika Anggriana, Noviyanti Kartika Dewi. 2016. "Identifikasi Permasalahan Gelandangan dan Pengemis di UPT Rehabilitasi Sosial Gelandangan dan Pengemis." INQUIRY Jurnal Ilmiah Psikologi 7(1): 30-40.

Umi Supraptiningsih. 2016. "Karakteristik Pengemis Perempuan Di Kecamatan Tlanakan Kabupaten Pamekasan.” Nuansa 13(2): 357-81. 
